\title{
Palmitoleate attenuates diet induced insulin resistance and hepatic inflammation independently of PPAR- $\alpha$
}

\author{
Camila O Souza ${ }^{1 *}$, Alexandre A de S Teixeira', Edson A de Lima', Helena A Batatinha', Sandro M Hirabara², \\ William T Festuccia ${ }^{3}$, José Cesar Rosa Neto ${ }^{1}$
}

From Metabolism, Diet and Disease 2014: Cancer and metabolism

Washington DC, USA. 28-30 May 2014

\section{Background}

Previous studies have showed that the lipokine palmitoleic acid (or palmitoleate) reduces diet induced muscle and liver inflammation and insulin resistance [1] and increases adipose tissue lipolysis, the latter through a mechanism that depends on PPAR- $\alpha$ [2]. Here we tested whether palmitoleate protects from the deleterious effects of a high fat diet (HFD) on glucose homeostasis and liver inflammation and whether PPAR- $\alpha$ is involved in these actions.

\section{Materials and methods}

C57BL (C57) and PPAR- $\alpha$ knockout (KO) mice fed either with a balanced (BD) or HFD during 12 weeks were treated after the 10th week with oleic acid (OLA, $300 \mathrm{mg} / \mathrm{kg}$ of b.w.) or palmitoleate (PMA, $300 \mathrm{mg} / \mathrm{kg}$ of b.w.) and evaluated for glucose and insulin tolerances (GTT and ITT), glucose uptake and metabolism, serum levels of aspartate aminotransferase (AST) and hepatic triacylglycerol content and cytokines levels (ELISA) and gene expression (qRT-PCR).

\section{Results}

HFD promotes insulin resistance and hepatic steatosis in both $\mathrm{C} 57$ and $\mathrm{KO}$ as evidenced by the reduced $(\mathrm{p}<0.05)$ muscle insulin stimulated glucose uptake and incorporation and increased $(\mathrm{p}<0.05)$ hepatic triacylglycerol content and plasma AST levels. Surprisingly, the hepatic steatosis induced by HFD was associated with liver inflammation in $\mathrm{KO}$, but not $\mathrm{C} 57$ mice as shown by the increased $(\mathrm{p}<0.05)$ hepatic levels of IL1- $\beta$, IL-12 and TNF- $\alpha$. In spite of these genotype specific phenotypes, HFD increased $(\mathrm{p}<0.05)$

'Department of Cell and Developmental Biology, University of São Paulo,

São Paulo, São Paulo, 05508-000, Brazil

Full list of author information is available at the end of the article
TLR4 expression and decreased $(\mathrm{p}<0.05)$ the IL1-Ra expression similarly in both $\mathrm{C} 57$ and $\mathrm{KO}$. Independently of mice genotype, palmitoleate markedly attenuated the insulin resistance induced by HFD as evidenced by the improved glucose tolerance and response to insulin in the ITT $(\mathrm{p}<0.05)$ and increased glucose uptake and incorporation in muscle in vitro $(\mathrm{p}<0.05)$. Furthermore, palmitoleate reduced $(p<0.05)$ the serum levels of AST in C57 and decreased $(p<0.05)$ the hepatic levels of IL1- $\beta$ and IL-12 in KO mice. Finally, palmitoleate reduced the hepatic TLR-4 expression $(\mathrm{p}<0.05)$ and increased IL-1Ra expression $(\mathrm{p}<0.05)$ in $\mathrm{C} 57$ but not in KO.

\section{Conclusions}

We concluded that palmitoleate attenuates diet induced insulin resistance, hepatic steatosis, inflammation and damage through mechanisms that do not depend on PPAR- $\alpha$.

\section{Acknowledgements}

FAPESP, CNPq, CAPES

\section{Authors' details \\ ${ }^{1}$ Department of Cell and Developmental Biology, University of São Paulo, São Paulo, São Paulo, 05508-000, Brazil. Institute of Physical Activity Sciences and Sports, Cruzeiro do Sul University, São Paulo, São Paulo, 01506-000, Brazil. ${ }^{3}$ Department of Physiology and Biophysics, University of São Paulo, São Paulo, São Paulo, 05508-000, Brazil.}

Published: 28 May 2014

References

1. Cao H, Gerhold K, Mayers JR, et al: Identification of a lipokine, a lipid hormone linking adipose tissue to systemic metabolism. Cell 2008, 134:933-944. 
2. Bolsoni-Lopes A, Festuccia WT, Farias TS, et al: Palmitoleic acid (n-7) increases white adipocyte lipolysis and lipase content in a

PPARalphadependent manner. Am J Physiol Endocrinol Metab 2013, 305: E1093-E1102.

doi:10.1186/2049-3002-2-S1-P52

Cite this article as: Souza et al:: Palmitoleate attenuates diet induced insulin resistance and hepatic inflammation independently of PPAR- $\alpha$. Cancer \& Metabolism 2014 2(Suppl 1):P52.

Submit your next manuscript to BioMed Central and take full advantage of:

- Convenient online submission

- Thorough peer review

- No space constraints or color figure charges

- Immediate publication on acceptance

- Inclusion in PubMed, CAS, Scopus and Google Scholar

- Research which is freely available for redistribution

Submit your manuscript at www.biomedcentral.com/submit
() Biomed Central 